DOI: https://doi.org/10.31933/jimt.v2i5 Received: 8 April 2021, Revised: 25 Mei 2021, Publish: 13 Juni 2021

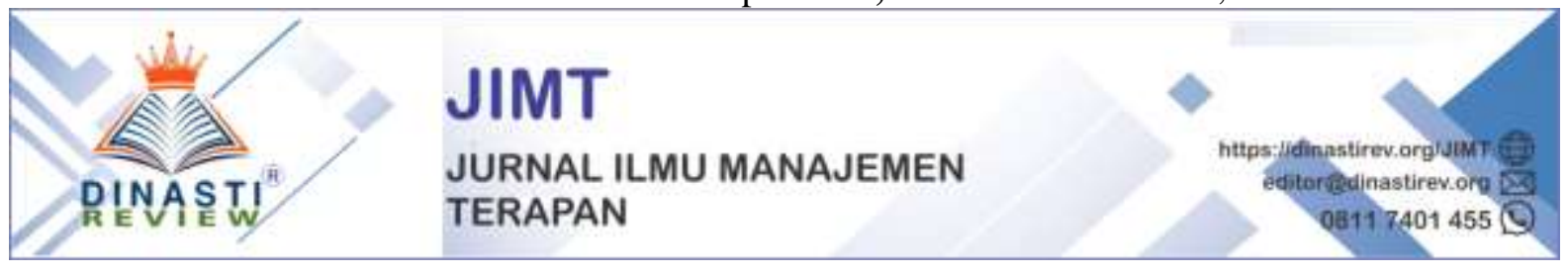

\title{
PRINSIP-PRINSIP YANG MEMPENGARUHI STAKEHOLDERS PERSEROAN TERBATAS: KEADILAN DAN TRANSPARANSI (KAJIAN PUSTAKA ETIKA)
}

\author{
Jane Angelica1, Zelika Azzahra ${ }^{2}$ \\ 1) Fakultas Ekonomi \& Bisnis, Universitas Mercu Buana, janeangelica640@gmail.com \\ ${ }^{2)}$ Fakultas Ekonomi \& Bisnis, Universitas Mercu Buana, zelikaazzahra08@gmail.com
}

\section{Koresponden Penulis: Jane Angelica ${ }^{1}$}

\begin{abstract}
Abstrak: Riset terdahulu atau riset yang relevan sangat penting dalam suatu riset atau artikel ilmiah. Riset terdahulu atau riset yang relevan berfungsi untuk memperkuat teori dan fenomena hubungan atau pengaruh antar variabel. Artikel ini mereview faktor-faktor yang mempengaruhi perlindungan suatu studi literatur stakeholders perseroan terbatas. Hasil artikel literature review ini adalah: 1) prinsip keadilan berpengaruh terhadap stakeholders perseroan terbatas dan 2) prinsip transparansi berpengaruh terhadap stakeholders perseroan terbatas.
\end{abstract}

Kata kunci: keadilan, transparansi, dan perseroan terbatas.

\section{PENDAHULUAN}

\section{Latar Belakang Masalah}

Hakikat corporate atau perusahaan yang menjadi objek dari Undang-Undang Negara Republik Indonesia Nomor 40 Tahun 2007 tentang Perseroan Terbatas (selanjutnya disingkat UUPT 2007), yaitu tentang perusahaan sebagai badan hukum dan entitas mandiri yang dilanjutkan dengan memahami hakikat governance atau pengelolaan. Kedudukan perusahaan sebagai badan hukum dan entitas hukum mandiri telah diatur dalam UUPT 2007. Perusahaan sebagai badan hukum secara tegas diatur pada pasal 1 angka 1 UUPT 2007 yang menyatakan: "Perseroan terbatas, yang selanjutnya disebut perseroan, adalah badan hukum yang merupakan persekutuan modal, didirikan berdasarkan perjanjian, melakukan kegiatan usaha dengan modal dasar yang seluruhnya terbagi dalam saham dan memenuhi persyaratan yang ditetapkan dalam undang-undang ini serta peraturan pelaksanaannya". Sedangkan perusahaan sebagai entitas hukum mandiri tidak diatur secara eksplisit dalam UUPT 2007 tetapi dapat ditemukan karakternya pada pasal 3 ayat (1) UUPT 2007 yang menegaskan bahwa : "Pemegang saham perseroan tidak bertanggung jawab secara pribadi atas perikatan yang dibuat atas nama perseroan dan tidak bertanggung jawab atas kerugian perseroan melebihi saham yang dimiliki”.

Pengelolaan perusahaan yang baik adalah suatu proses dan struktur yang digunakan untuk meningkatkan keberhasilan usaha dan akuntabilitas perusahaan guna meningkatkan nilai perusahaan (corporate value) dalam jangka panjang dengan memperhatikan kepentingan stakeholders berlandaskan moral, etika, dan peraturan perundang-undangan dibagi 3 (tiga) aktivitas: menerapkan kebijakan nasional, menyempurnakan kerangka regulasi, dan 
membangun inisiatif sektor swasta. Pada tanggal 16 Agustus 2007, Pemerintah Republik Indonesia telah mengeluarkan Undang-Undang Nomor 40 Tahun 2007 tentang Perseroan Terbatas (selanjutnya disebut UUPT) yang berfungsi untuk mengatur kegiatan suatu perusahaan yang melingkupi aspek organisasi, bisnis, dan budaya perusahaan.

Hukum perusahaan di Indonesia, dalam Undang-Undang Nomor 40 Tahun 2007 tentang Perseroan Terbatas mengenal prinsip-prinsip pengelolaan perusahaan yang baik (good corporate governance), walaupun pengaturannya relatif sumir, karena belum atau tidak diterapkan prinsip-prinsip tersebut, misalnya prinsip pencatatan saham atau bukti pemilikan maupun prinsip perolehan informasi yang relevan mengenai perseroan pada waktu yang tepat, kecuali pada perusahaan publik masih belum sepenuhnya diterapkan. Bagi perusahaan swasta yang berskala menengah dan kecil yang kebanyakan tidak tercatat, bahkan jarang dilakukan pertanggungjawaban direksi pada setiap akhir tahun buku perseroan atau dilakukan audit, sehingga tidak memberikan jaminan perlindungan hukum bagi para stakeholders.

Perlindungan hukum bagi stakeholders, termasuk pemegang saham minoritas belum optimal dikarenakan: posisi dan lemahnya peranan stakeholders maupun pengelola perusahaan itu sendiri; pengamatan pasar masih kurang karena stakeholders dan pesaing sering sebagai bagian konglomerat yang dimiliki oleh keluarga yang sama juga ikut memiliki perusahaan pemberi pinjaman dana; dan perlindungan hukum stakeholders masih lemah akibat sistem peradilan yang tidak efisien termasuk Undang-Undang Kepailitan dan prosedurnya tidak aktif di Indonesia.

Prinsip-prinsip utama dari good corporate governance (GCG) yang menjadi indikator, yang ditawarkan oleh Organization for Economic Cooperation and Development (OECD), adalah: 1. Fairness (Kewajaran); 2.Disclosure/Transparency (Keterbukaan/Transparansi); 3. Accountability (Akuntabilitas); 4. Responsibility (Responsibilitas);

Artikel ini membahas pengaruh prinsip keadilan dan prinsip transparansi terhadap stakeholders dalam perseroan terbatas.

\section{Rumusan Masalah}

Berdasarkan latar belakang akan di rumuskan masalah yang akan di bahas pada artikel literature review agar lebih focus pada kajian pustaka dan hasil serta pembahasan nanti, yaitu:

1. Apakah prinsip keadilan memiliki hubungan dan berpengaruh terhadap stakeholders perseroan terbatas?

2. Apakah prinsip transparansi memiliki hubungan dan berpengaruh terhadap stakeholders perseroan terbatas?

\section{KAJIAN TEORI}

\section{Stakeholders dalam Perseroan Terbatas}

Kata stakeholders telah dipakai oleh banyak pihak dan hubungannya dengan berbagai ilmu dan konteks, misalnya manajemen bisnis, ilmu komunikasi, pengelolaan sumber daya alam, sosiologi, dan lain-lain. Lembaga-lembaga publik telah menggunakan secara luas istilah stakeholders ini ke dalam proses-proses pengambilan dan implementasi keputusan. Secara sederhana, stakeholders sering dinyatakan sebagai para pihak, lintas pelaku, atau pihak-pihak yang terkait dengan suatu isu atau suatu rencana. Pendekatan stakeholders muncul pada pertengahan tahun 1980-an. Latar belakang pendekatan stakeholders adalah keinginan untuk membangun suatu kerangka kerja yang responsif terhadap masalah yang dihadapi para manajer saat itu yaitu perubahan lingkungan (Freeman dan McVea, 2001). Tujuan dari manajemen stakeholder adalah untuk merancang metode untuk mengelola berbagai kelompok dan hubungan yang dihasilkan dengan cara yang strategis (Freeman dan McVea,2001). Definisi stakeholders menurut Freeman dan McVea adalah individu yang dapat mempengaruhi atau dipengaruhi oleh pencapaian tujuan organisasi.

Dalam praktik sangat banyak dijumpai perusahaan berbentuk perseroan terbatas. 
Perseroan terbatas adalah badan hukum yang merupakan persekutuan modal didirikan berdasarkan perjanjian, melakukan kegiatan usaha dengan modal dasar yang seluruhnya terbagi dalam saham dan memenuhi dalam persyaratan yang ditetapkan dalam Undang Undang Nomor 40 Tahun 2007 tentang Perseroan Terbatas ini serta pelaksanaannya. Bahkan, berbisnis dengan membentuk perseroan terbatas ini, terutama untuk bisnis yang serius atau bisnis besar, merupakan model berbisnis yang paling lazim dilakukan, sehingga dapat dipastikan bahwa jumlah dari perseroan terbatas di Indonesia jauh melebihi jumlah bentuk bisnis lain, seperti firma, perusahaan komanditer, koperasi dan lain-lain. Terhadap perseroan terbatas ini, dalam beberapa bahasa disebut sebagai berikut:

1. Dalam bahasa Inggris disebut dengan limited (Ltd), company, atau limited liability company atau pun limited (Ltd) corporation.

2. Dalam bahasa Belanda disebut dengan naamlooze, vennootschap, atau yang sering disingkat dengan NV saja.

3. Dalam bahasa Jerman terhadap perseroan terbatas ini disebut dengan gesellschaft mit beschrankter haftung.

4. Dalam bahasa Spanyol disebut dengan sociedad de responsabilidad limitada.

Definisi-definisi lain yang diberikan kepada suatu perseroan terbatas adalah sebagai berikut ini :

1. Suatu manusia semu atau badan hukum yang diciptakan oleh hukum, yang dapat saja (sesuai hukum setempat) hanya terdiri dari 1 (satu) orang anggota saja beserta para ahli warisnya, tetapi yang lebih lazim terdiri dari sekelompok individu sebagai anggota, yang oleh hukum badan hukum tersebut dipandang terpisah dari para anggotanya di mana keberadaannya tetap eksis terlepas dari saling bergantinya para anggota, badan hukum mana dapat berdiri untuk waktu yang tidak terbatas (sesuai hukum setempat), atau berdiri untuk jangka waktu tertentu, dan dapat melakukan kegiatan sendiri untuk kepentingan bersama dari anggota, kegiatan mana berada dalam ruang lingkup yang ditentukan oleh hukum yang berlaku.

2. Suatu manusia semu yang diciptakan oleh hukum yang terdiri dari, baik 1 (satu) orang anggota (jika hukum memungkinkan untuk itu), yakni yang disebut dengan perusahaan 1 (satu) orang maupun yang terdiri dari sekumpulan atau beberapa orang anggota, yakni yang disebut dengan perusahaan banyak orang.

3. Suatu badan intelektual yang diciptakan oleh hukum, yang terdiri dari beberapa orang individu, yang bernaung di bawah 1 (satu) nama bersama, di mana perseroan terbatas tersebut sebagai badan intelektual tetap sama dan eksis meskipun para anggotanya saling berubahubah.

Menurut ketentuan UUPT 2007 dalam pasal 2 disebutkan bahwa perseroan harus mempunyai maksud dan tujuan serta kegiatan usaha yang tidak bertentangan dengan ketentuan peraturan perundang-undangan, ketertiban umum, dan kesusilaan. Perusahaan mempunyai kegiatan usaha, sehingga perseroan mempunyai maksud dan tujuan serta kegiatan usaha yang tidak bertentangan dengan ketentuan peraturan perundang-undangan, ketertiban umum, dan kesusilaan (pasal 2 UUPT 2007).

Pengelolaan perusahaan yang baik adalah suatu proses dan struktur yang digunakan untuk meningkatkan keberhasilan usaha dan akuntabilitas perusahaan guna meningkatkan nilai perusahaan (corporate value) dalam jangka panjang dengan memperhatikan kepentingan stakeholders.

Prinsip-prinsip pengelolaan perusahaan yang baik menurut Organization for Economic Corporation and Devolopment (OECD) yang mencakup:

a. hak-hak pemegang saham (the rights of shareholders) dan perlindungannya;

b. perlindungan yang adil bagi seluruh pemegang saham (the equitable treatment of shareholders);

c. peranan stakeholders dalam corporate governance (the role of stakeholders in corporate 


\section{governance);}

d. pengungkapan dan transparansi (disclosure and transparency);

e. tanggung jawab direksi dan komisaris (the responsibility of the board) terhadap perusahaan, pemegang saham dan pihak berkepentingan lainnya.

Prinsip-prinsip tersebut tidak mengikat hanya memberikan pedoman bagi negaranegara untuk memperbaiki pengelolaan perusahaan di negara mereka, sebagai berikut: a. Prinsip Keadilan atau Perlakuan Setara (Fairness or Equitable Treatment).

Artinya harus memproteksi hak-hak pemegang saham mengakui hak kepemilikan pemegang saham berhubungan "keadilan", persamaan, perlindungan hak pemegang saham minoritas.

b. Prinsip Transparansi (Transparency)

Berkaitan dengan perusahaan, seperti: standar laporan keuangan, kinerja, kepemilikan, dan kepemimpinan perusahaan. Adanya keterbukaan informasi material (disclosure information) secara akurat, memadai, dan tepat waktu dapat diantisipasi oleh stakeholders, jika tidak memperoleh informasi.

c. Prinsip Pertanggungjawaban atau Akuntabilitas (Accountability)

Pengelolaan iktikad baik bertanggung jawab untuk kepentingan usaha perseroan memastikan pedoman strategis perusahaan, pengawasan efektif atas pengelolaan pertanggungjawaban direktur dan komisaris berbasiskan kepercayaan bagi pemegang saham.

d. Prinsip Tanggung Jawab atau Responsibilitas (Responsibility)

Tujuan perseroan selain profit harus memperlihatkan keseimbangan, kepentingan, dan hak para pihak yang berkepentingan atas perseroan secara luas mendorong kerja sama antara perusahaan dan publik (stakeholders) dalam menciptakan kemakmuran, kesempatan kerja, dan pendukung perusahaan bersifat finansial.

Stakeholders dalam perseroan terbatas ini sudah banyak di teliti oleh peneliti sebelumnya, di antaranya adalah: (Hartanto, 2019) dan (Pramanditya, 2015).

\section{Prinsip Keadilan}

Terdapat empat prinsip dalam good corporate governance (GCG) dalam Perseroan Terbatas, yaitu transaparansi (transparency), keadilan (fairness), akuntabilitas (accountability), dan tanggung jawab (responsibility). Di dalam prinsip-prinsip ini yang mengatur tentang kesetaraan atau persamaan hak diantara pemegang saham minoritas dan pemegang saham mayoritas adalah prinsip keadilan (fairness). Direksi merupakan organ yang memegang peranan penting dalam menentukan maju atau mundurnya suatu perusahaan, karena yang menjadi salah satu sebab rentannya perusahaan-perusahaan di Indonesia terhadap gejolak perekonomian adalah lemahnya penerapan good corporate governance (GCG). Dan yang menentukan keberhasilan dari konsep ini adalah direksi. Kepentingan antara pemegang saham mayoritas dengan pemegang saham minoritas dalam suatu perseroan terbatas seringkali bertentangan satu sama lain. Minority shareholders atau pemegang saham minoritas tidak jarang hanya dijadikan sebagai pelengkap dalam sebuah perusahaan.

Keadilan atau biasa yang disebut dengan fairness secara sederhana mengandung arti sebagai perlakuan yang adil dan kesetaraan didalam memenuhi hak-hak stakeholder yang timbul akibat perjanjian dan peraturan perundangan yang berlaku. Namun tidak hanya itu, fairness juga berati mencakup tentang adanya kejelasan hak-hak pemodal, sistem hukum, dan penegakan peraturan guna melindungi hak-hak inverstor khususnya dalam hal ini adalah hak pemegang saham minoritas untuk terhindari dari bentuk-bentuk kecurangan yang ada. Banyak tindakan curang yang dapat saja dilakukan didalam perseroan oleh direksi yang dikontrol oleh pemegang saham mayoritas. Bentuk kecurangan yang dimaksud bisa berupa insider trading (transaksi yang melibatkan informasi orang dalam), dilusi saham (nilai perusahaan berkurang), KKN, ataupun keputusan-keputusan yang sewaktu-waktu bisa 
menimbulkan kerugian seperti pembelian kembali saham yang telah dikeluarkan, penerbitan saham baru, merger, akuisisi, atau juga termasuk pengambil ahlian perusahaan lain. 
Kecurangan-kecurangan diatas bisa saja terjadi karena berasal dari adanya benturan atau pertentangan kepentingan antara manajemen (dewan komisaris dan direksi) dengan pemegang saham, ataupun antara pemegang saham itu sendiri, yaitu pemegang saham minoritas dan pemegang saham mayoritas. Sebelum membahas tentang apa yang menjadi hak pemegang saham minoritas, perlu diketahui terlebih dahulu mengenai hakhak dasar dari pemegang saham pada umumnya yang harus dilindungi, yang dibagi menjadi dua golongan, antara lain hak-hak yang berkaitan dengan kepemilikan perusahaan dan hak-hak yang diciptakan sebagai konsekuensi pemisahan fungsi pemegang saham dan dewan pengurus.

Permasalahan bagi stakeholders perusahaan yang mendapatkan perlakuan tidak adil melalui upaya penegakan hukum (law enforcement). Perusahaan di Indonesia masih belum mencerminkan perlindungan menyeluruh bagi stakeholders dan belum memihak pada rasa keadilan yang diharapkan masyarakat.

Melalui adanya Undang-Undang Nomor 40 Tahun 2007 tentang Perseroan Terbatas, diberdayakan pemegang saham minoritas untuk tidak diabaikan kepentingannya oleh pihak manapun termasuk dalam hal ini adalah pihak pemegang saham mayoritas.

Secara garis besar dari hasil penelitian norma-norma yang mengatur prinsip-prinsip pengelolaan perusahaan yang baik dalam Undang-Undang Nomor 40 Tahun 2007 tentang Perseroan Terbatas dapat dijabarkan sebagai berikut:

1. Pemegang saham minoritas mendapatkan perlakuan tidak adil, karena:

a) Kurangnya ketentuan dalam perundang-undangan yang melindungi hak-hak pemegang saham minoritas. Pada kenyataannya, sekalipun ketentuan ada, tetapi dirasakan masih belum cukup bagi pemegang saham minoritas dirugikan kepentingannya oleh pemegang saham mayoritas beriktikad buruk. Selain itu, adanya kewenangan diberikan UUPT kepada organ RUPS untuk menetapkan kebijakan perseroan, secara tegas tidak mengatur adanya kewajiban partisipasi aktif bagi pemegang saham minoritas untuk mengajukan pendapatnya;

b) Sikap dan perilaku pemegang saham mayoritas, direksi atau komisaris yang memiliki karakter moral hazard;

c) Posisi lemah pemegang saham minoritas karena kurangnya modal, pengetahuan, keterampilan dan kemampuan untuk mengelola PT, sehingga pemegang saham minoritas tersebut tidak mampu untuk menghadapi sikap dan perilaku dari pemegang saham mayoritas yang memiliki iktikad tidak baik. Peranan stakeholders berlandaskan pada prinsip the role of stakeholders bahwa corporate governance harus mengakui hak-hak stakeholders yang ditetapkan hukum dan mendorong kerjasama efektif antara perusahaan dan stakeholders menciptakan kemakmuran, pekerjaan, kelangsungan perusahaan secara finansial sehat: 1) kerangka kerja corporate governance harus memastikan bahwa hak- hak stakeholder yang dilindungi hukum dihargai; 2) apabila kepentingan the stakeholder dilindungi hukum, maka stakeholder harus berkesempatan untuk memperoleh ganti rugi pelanggaran efektif dan hakhak mereka; 3) kerangka kerja corporate governance memperoleh mekanisme penguatan kinerja untuk stakeholder; 4) apabila stakeholders berpartisipasi dalam proses corporate governance, maka mereka harus mempunyai akses terhadap informasi yang relevan.

Prinsip keadilan sudah banyak di teliti oleh peneliti sebelumnya, di antaranya adalah: (Apriliani, 2015).

\section{Prinsip Transparansi}

Prinsip pengelolaan usaha yang baik pengaturan tanggung jawab dari setiap organ yang ada di dalam perserseroan terbatas akan memengaruhi desain kewenangan dan tanggung jawab yang ditetapkan di dalam anggaran dasar. Tanpa adanya direksi dan komisaris, suatu PT tidak dapat menjalankan fungsinya sebagai sebuah institusi atau badan yang melakukan aktivitas usaha untuk mencari keuntungan ekonomis, maka dilakukan pengawasan oleh dewan komisaris dan dibatasi oleh RUPS sebagai pemilik perseroan melalui ketentuan yang 
diatur dalam UUPT 2007, Undang-Undang Pasar Modal untuk perusahaan terbuka, dan anggaran dasar dari perseroan yang bersangkutan.

Anggota dewan komisaris merangkap sebagai dewan direksi dan kedua organ inilah yang disebut sebagai board of directors. Perusahaan di Indonesia menggunakan sistem Eropa Kontinental disebut two-board system terdapat pemisahan tegas antara keanggotaan dewan komisaris sebagai pengawas, dan dewan direksi sebagai eksekutif dalam perusahaan. Dalam UUPT 2007 menganut model yang membedakan tugas dan kewenangan direksi dengan komisaris, maka peraturan perseroan terbatas memiliki ruang lingkup kedudukan dan tanggung jawab komisaris, direksi, dan para pemegang saham. Peranan dan tanggung jawab komite audit akan dituangkan dalam Komite Audit Charter yang secara umum dikelompokkan menjadi tiga bagian besar, yaitu financial reporting, corporate governance, dan risk and control management. Dewan komisaris yang aktif, canggih, ahli, beragam dan terpenting independen menjalankan fungsinya secara efektif dan dibantu komite audit terbaik untuk ditempatkan dalam memastikan prinsip-prinsip pengelolaan perusahaan yang baik (good corporate governance) berjalan baik sehingga bentuk kecurangan (fraud) atau keterpurukan bisnis dapat dihindari.

Berdasarkan ketentuan dalam UUPT 2007 terdapat norma mengatur prinsip transparansi terkait fungsi direksi perusahaan terdapat dalam pasal 92 ayat (1) direksi menjalankan pengurusan perseroan untuk kepentingan perseroan dan sesuai dengan maksud dan tujuan perseroan. Pasal 97 ayat (1) direksi bertanggung jawab atas pengurusan perseroan sebagaimana dimaksud dalam pasal 92 ayat (1). Ketentuan norma yang mengatur pengesahan suatu perseroan terbatas dalam pasal 9 ayat (1) Untuk memperoleh keputusan menteri mengenai pengesahan badan hukum perseroan sebagaimana dimaksud dalam pasal 7 ayat (4), pendiri bersama-sama mengajukan permohonan melalui jasa teknologi informasi sistem administrasi badan hukum secara elektronik kepada menteri dengan mengisi format isian lengkap.

Berdasarkan ketentuan dalam UUPT 2007 terdapat norma mengatur prinsip transparansi terkait dengan pengungkapan informasi perusahaan dalam pasal 92 ayat (4) perseroan yang kegiatan usahanya berkaitan dengan menghimpun atau mengelola dana masyarakat, perseroan menerbitkan surat pengakuan utang kepada masyarakat, PT wajib mempunyai paling sedikit 2 (dua) orang anggota direksi yang berkewajiban: a) membuat daftar pemegang saham, daftar khusus, risalah RUPS, risalah rapat direksi, b) membuat laporan tahunan sebagaimana dimaksud dalam pasal 66, c) dokumen keuangan perseroan sebagaimana dimaksud dalam Undang-Undang Dokumen Perusahaan, d) memelihara seluruh daftar, risalah, dan dokumen keuangan perseroan sebagaimana dimaksud pada huruf a dan huruf $b$ dan dokumen perseroan lainnya (pasal 100 ayat (1) UUPT 2007). Penyampaian informasi tentang perusahaan dengan benar dan tepat waktunya kepada pemegang saham akan dapat membantu kepadanya sebagai bahan untuk berperan serta dalam pengambilan keputusan mengenai perubahan-perubahan yang mendasar pada perseroan.

Berdasarkan ketentuan dalam UUPT 2007 terdapat norma yang mengatur prinsip transparansi yang terkait dengan ketentuan penggabungan, peleburan, pengambil alihan, dan pemisahan atau yang lebih dikenal istilah merger, konsolidasi, dan akuisisi (MKA) yang diatur lebih sistematis, lebih jelas dan terperinci. UUPT 2007 ini memang jelas mengatur masalah MKA dalam banyak pasal, bayangkan sampai 12 pasal (pasal 122 sampai dengan pasal 134). pengaturan MKA dalam UUPT 2007 dapat menjawab masalah yang timbul dalam praktik atas tidak jelasnya pengaturan MKA ini pada UUPT 2007 berlaku saat ini.

Dalam UUPT 2007 ini adalah mengenai pemisahan usaha bahwa norma ini bersifat baru dan diatur dalam pasal 135 dan pasal 136 UUPT 2007 sebagai berikut: (1) Pemisahan dapat dilakukan dengan cara pemisahan murni atau pemisahan tidak murni, (2) Pemisahan murni sebagaimana dimaksud pada ayat (1) huruf mengakibatkan seluruh aktiva dan pasiva 
Perseroan beralih karena hukum kepada dua perseroan lain menerima peralihan dan perseroan melakukan pemisahan usaha berakhir karena hukum, (3) Pemisahan tidak murni sebagaimana dimaksud pada ayat (1) huruf b mengakibatkan sebagian aktiva dan pasiva perseroan beralih karena hukum kepada 1 (satu) Perseroan lain atau lebih menerima peralihan, dan perseroan yang melakukan pemisahan tersebut tetap ada.

Prinsip transparansi diwujudkan antara lain dengan mengembangkan sistem akuntansi yang berbasis standar akuntansi dan best practice yang menjamin laporan keuangan dan pengungkapan yang berkualitas, mengembangkan informasi technology dan management information system (MIS) untuk menjamin adanya pengukuran kinerja yang memadai dan proses pengambilan keputusan yang efektif oleh komisaris dan direksi, mengembangkan enterprise risk management yang memastikan bahwa semua resiko signifikan telah diidentifikasi, diukur, dan dapat dikelola pada tingkat toleransi yang jelas, serta mengumumkan jabatan yang kosong secara terbuka

Prinsip transparansi sudah banyak di teliti oleh peneliti sebelumnya, di antaranya adalah: (Yunita, 2020).

\section{METODE PENULISAN}

Metode penulisan artikel ilmiah ini menggunakan studi literatur dan studi kepustakaan dengan mengkaji berbagai referensi sesuai dengan teori yang dibahas. Disamping itu menganalisis artikel-artikel ilmiah yang bereputasi dan juga artikel ilmiah dari jurnal yang belum bereputasi. Semua artikel ilmiah yang di citasi bersumber dari Mendeley dan Google Cendekia.

\section{PEMBAHASAN}

\section{Pengaruh atau Hubungan Prinsip Keadilan terhadap Stakeholders dalam Perseroan Terbatas}

Berdasarkan kajian Legal Contractual Theory diterapkan keputusan suara mayoritas dalam perjanjian antar pemegang saham mencerminkan arah dari perseroan itu sendiri sebagai pemilik perusahaan tergantung direksi untuk mengoptimalkan dana investasi yang telah ditanamkan. Prinsip keadilan terhadap perlindungan hukum stakeholders, yaitu:

a. Prinsip Perlindungan terhadap Hak-Hak Pemegang Saham

1) Prinsip Perlindungan Hak Pemegang Saham

Adapun salah satu prinsip yang diterapkan dalam pengelolaan perusahaan yang baik adalah prinsip persamaan perlakuan terhadap seluruh pemegang saham sebagai salah satu aspek yang perlu diprioritaskan dalam penerapan pengelolaan perusahaan yang baik di Indonesia, karena UUPT 2007 telah jauh lebih maju dibandingkan ketentuan UUPT 1995 dalam menyediakan fasilitas perlindungan pemegang saham minoritas masih kontrovesi sekadar hanya wacana normatif. Pemegang saham minoritas harus diberikan hak voting akumulatif dalam proses nominasi anggota dewan komisaris dan direksi, misalnya memberikan hak kepada pemegang saham minoritas tanpa harus melanggar ketentuan one share one vote.

2) Prinsip Persamaan Perlakuan terhadap Pemegang Saham

Dalam UUPT 2007 pasal 85 ayat (1) bahwa pemegang saham, baik sendiri maupun diwakili berdasarkan surat kuasa berhak menghadiri RUPS dan menggunakan hak suara sesuai jumlah saham yang dimilikinya. Prinsip-prinsip pengelolaan perusahaan yang baik harus memastikan perlakuan yang sama (equitable treatment for shareholders) bagi pemegang saham minoritas dan asing, yang mengutamakan equal job opportunity. Prinsipnya pemegang saham harus berkesempatan untuk memperoleh ganti rugi pelanggaran (redress for violation) yang efektif atas hak-haknya: a) Semua pemegang saham dari kelompok yang sama harus diperlakukan secara sama atau adil; b) Praktik-praktik insident trading dan self-dealing yang bersifat penyalahgunaan harus dilarang; c) Anggota dewan komisaris dan manajer 
disyaratkan untuk mengungkapkan setiap kepentingan material dalam transaksi atau hal-hal yang mempengaruhi perusahaan. Pemegang saham berhak meminta perseroan supaya sahamnya dibeli harga wajar jika dia tidak menyetujui tindakan perseroan yang merugikan pemegang saham atau perseroan, berupa perubahan anggaran dasar, pengalihan atau penjaminan kekayaan perseroan yang mempunyai nilai lebih dari 50\% (lima puluh persen) kekayaan bersih perseroan, dan penggabungan, peleburan, pengambilalihan, atau pemisahan (Pasa1 62 ayat (1) UUPT 2007).

Ketentuan pasal ini mewajibkan perseroan membeli saham dari pemegang saham minoritas, maupun sanksi jika perseroan menolak membeli saham tersebut, dengan katalain pemegang saham minoritas tertutup untuk memanfaatkan pasal 62 ayat (1) UUPT 2007. Perlindungan hukum bagi pemegang saham pada saat perusahaan melakukan perbuatan hukum antara lain: penggabungan, peleburan, pengambilan, dan pemisahan sudah diatur dalam pasal 126 UUPT 2007, yaitu:

(1) Perbuatan hukum penggabungan, peleburan, pengambil alihan, atau pemisahan wajib memperhatikan kepentingan:

a) Perseroan, pemegang saham minoritas, karyawan perseroan;

b) Kreditor dan mitra usaha lainnya dari perseroan;

c) Masyarakat dan persaingan sehat dalam melakukan usaha.

(2) Pemegang saham yang tidak setuju terhadap keputusan RUPS mengenai penggabungan, peleburan, pengambilalihan, atau pemisahan dimaksud ayat (1) hanya boleh menggunakan haknya sebagaimana dimaksud dalam pasal 62.

Perlindungan hukum pemegang saham (shareholders) berdasarkan teori pendirian perseroan berlandaskan doktrin piercing the corporate veil merupakan doktrin hukum perseroan di common law system itu telah diintegrasikan ke dalam UUPT 2007 yang dituangkan dalam pasal 3 ayat (2). Dalam ketentuan tersebut, diketahui bahwa untuk terjadinya piercing the corporate veil dipersyaratkan, yaitu persyaratan perseroan badan hukum belum atau tidak terpenuhi, pemegang saham yang bersangkutan baik langsung maupun tidak langsung dengan itikad buruk memanfaatkan perseroan semata-mata untuk kepentingan pribadi, pemegang saham yang bersangkutan terlibat dalam perbuatan melawan hukum dilakukan perseroan, dan pemegang saham bersangkutan langsung atau tidak langsung secara melawan hukum menggunakan kekayaan perseroan yang mengakibatkan kekayaan perseroan menjadi tidak cukup untuk melunasi utang perseroan.

Prinsip keadilan diterapkan bagi pemegang saham dengan istilah the right of shareholders, yaitu prinsip-prinsip perlindungan terhadap hak-hak pemegang saham. Prinsip keadilan dalam pengelolaan perusahaan yang baik (good corporate governance) harus melindungi hak-hak pemegang saham, yaitu:

a) Hak-Hak Pemegang Saham yang mencakup:

1) Metode dalam pencatatan kepemilikan (ownership registration);

2) Mengalihkan (covey) atau pemindahan saham;

3) Memperoleh informasi yang relevan tentang perusahaan pada waktu yang tepat dan berkala;

4) Berpartisipasi dan memberikan suara dalam rapat umum pemegang saham (RUPS);

5) Memilih anggota dewan komisaris;

6) Mendapatkan pembagian laba perusahaan;

b) Berhak untuk berpartisipasi secara memadai diberi informasi tentang keputusan dengan perubahan perusahaan fundamental, seperti: perubahan anggaran dasar, dokumen sejenis dari perusahaan, otoritas tambahan saham, transaksi luar biasa akibat penjualan perusahaan;

c) Berhak untuk berpartisipasi secara memadai diberi informasi tentang keputusan yang berkaitan dengan perubahan perusahaan yang fundamental, seperti: perubahan anggaran dasar 
atau dokumen sejenis dari perusahaan, otoritas tambahan saham, dan transaksi yang luar biasa sebagai akibat dari penjualan perusahaan;

d) Berhak mempunyai kesempatan berpartisipasi secara efektif dan memberi suara dalam rapat umum pemegang saham (general shareholder meeting) dan harus diberi informasi tentang peraturan, mencakup proses pemberian suara yang mempengaruhi RUPS;

e) Struktur modal yang memungkinkan pemegang saham tertentu untuk memperoleh suatu tingkat pengendalian yang tidak seimbang atau sepadan dengan kepemilikan ekuitas mereka harus diungkap;

f) Market for corporate control harus berfungsi dalam keadaan yang efisien dan transparan, misalnya peraturan dan prosedur yang mempengaruhi akuisisi tentang pengendalian korporat dalam pasar modal, transaksi yang luar biasa seperti merger, dan lain-lain.

g) Pemegang saham, investor kelembagaan harus mempertimbangkan biaya dan manfaat melaksanakan hak pemberian suara. Perlindungan hukum terhadap stakeholders, khususnya bagi hak pemegang saham di dalam UUPT 2007 pengaturannya relatif sumir, karena lebih banyak prinsip yang belum atau tidak diterapkan sesuai norma-norma dan prinsip-prinsip pengelolaan peruahaan yang baik (good corporate governance), misalnya prinsip pencatatan saham atau bukti pemilikan maupun prinsip perolehan informasi yang relevan mengenai perseroan pada waktu yang tepat, kecuali pada perusahaan publik, itupun masih belum sepenuhnya diterapkan.

Variabel prinsip keadilan dan stakeholders sudah banyak di teliti oleh peneliti sebelumnya, di antaranya adalah: (Dian Aprilliani, 2015).

\section{Pengaruh atau Hubungan Prinsip Transparansi terhadap Stakeholders dalam Perseroan Terbatas}

Secara normatif prinsip pengungkapan informasi perusahaan secara transparan dapat ditinjau melalui perbandingan hukum perusahaan dengan negara lain yang menurut UndangUndang Perseroan Terbatas Australia (corporation law), sebuah perusahaan tertutup harus menyatakan keterbukaan tujuan pemegang saham, maksudnya, apakah pemegang saham tersebut menguasai saham untuk dirinya sendiri atau untuk kepentingan pihak lain. Di Inggris ada Board of Trade (BOT) yang dapat menunjuk inspektur untuk menyelidiki pemilikan saham dalam sebuah perusahaan dan memaksa pihak tertentu memberikan keterangan atas kepentingan dalam saham juga berwenang membatasi transaksi atas saham (freezing order) diperlukan prinsip keterbukaan kepentingan (disclosure of interest) dalam tranksaksi akuisisi perusahaan lintas negara yang tidak hanya keterbukaan siapa pemiliknya, namun transparansi kepentingan sipemilik.

Masukan bagi pihak asing banyak yang menjadi kepanjangan tangan konglomerat Indonesia sendiri. UUPT 2007 belum punya pasal yang mengatur merger dengan pembiayaan utang (leveraged buy out, LBO), padahal akuisisi lintas negara menyangkut nilai transaksi besar, karena tidak jarang pembeli membutuhkan dana utang. Kasus Indonesia, tidak jarang pihak kreditur membuat syarat yang berat, misalnya, kreditur dapat meminta anak perusahaan untuk memberikan jaminan atas sejumlah utang perusahaan sasaran sesuai tujuan UUPT 2007 ini bahwa manajemen perseroan oleh direksi semata-mata untuk kepentingan perseroan. Utang-utang perusahaan induk yang tidak membawa manfaat bagi perusahaan anak jangan sampai membebani perusahaan anaknya. UUPT 2007 ini belum mewadahi peraturan hukum yang berlaku jika terjadi merger antar negara, seperti aturan di Jerman. Jika perusahaan Jerman menjadi calon pembeli perusahaan negara lain, maka harus tunduk kepada peraturan negara tempat perusahaan sasaran. Sebaliknya, jika ada perusahaan Jerman dibeli oleh perseroan negara lain, si pembeli harus mengikuti peraturan Jerman. Sedangkan di Indonesia keterbukaan tujuan pemegang saham masih belum memberikan perlindungan hukum bagi stakeholders, karena budaya timur dan patrimonialisme. 
Variabel prinsip transparansi dan stakeholders dalam perseroan terbatas sudah banyak di teliti oleh peneliti sebelumnya, di antaranya adalah: (Graziano, 2016).

\section{CONCEPTUAL FRAMEWORK}

Berdasarkan rumusan masalah penulisan artikel ini dan kajian studi literature review baik dari buku dan artikel yang relevan, maka diperoleh kerangka artikel seperti di bawah ini.

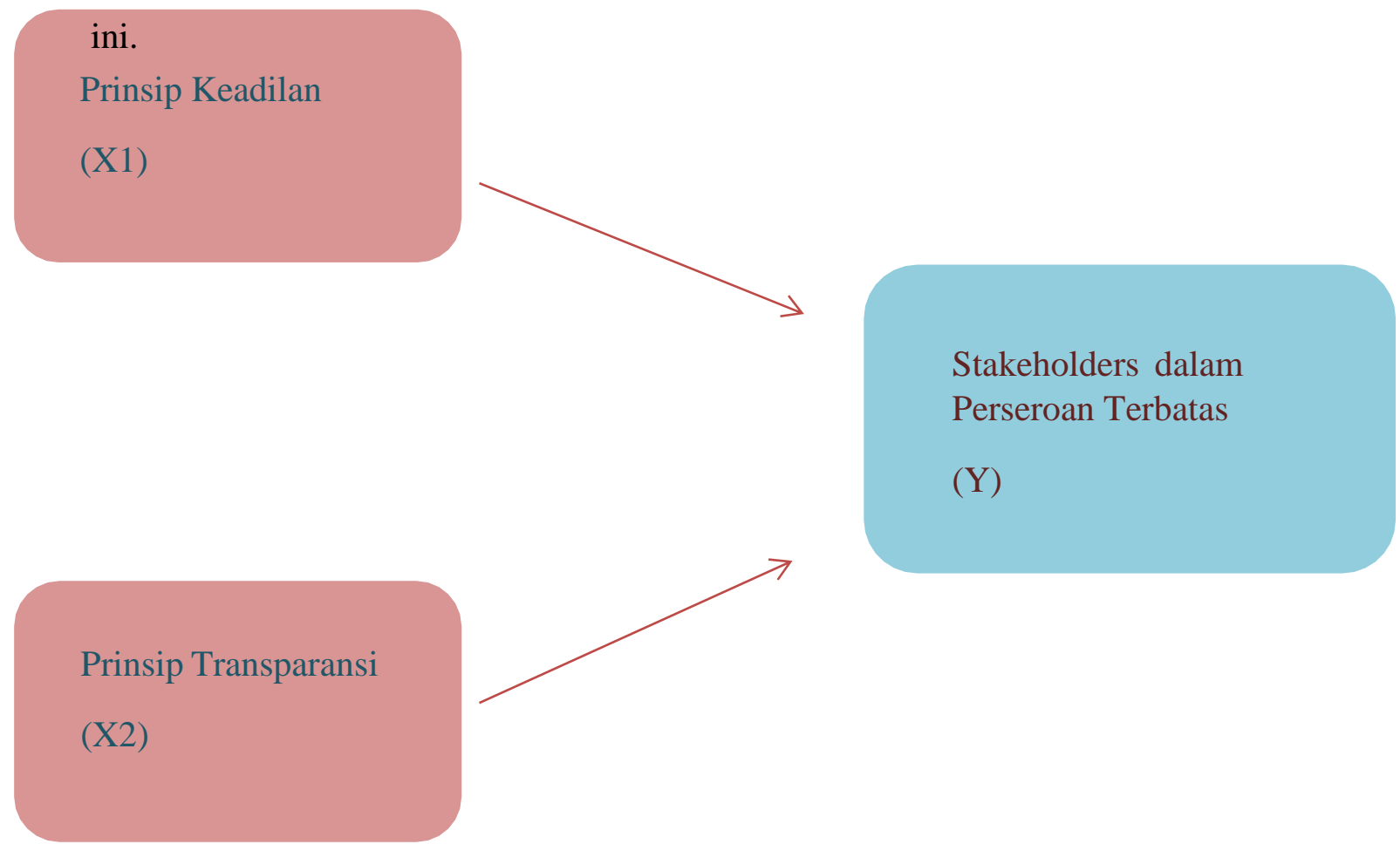

\section{Gambar 1: Conceptual Framework}

Berdasarkan kajian teori dan review hasil dari artikel yang relevan serta gambar dari conceptual framework, maka: prinsip keadilan dan prinsip transparansi berpengaruh terhadap stakeholders perseroan terbatas.

Selain dari tiga variabel ini yang mempengaruhi, masih ada variabel lain yang mempengaruhinya diantaranya adalah:

a. Prinsip tanggung jawab: (Hambali, 2019).

b. Prinsip akuntabilitas: (Maheswari, 2020).

\section{KESIMPULAN DAN SARAN \\ Kesimpulan}

Berdasarkan rumusan artikel dan pembahasan maka dapat di di rumuskan hipotesis untuk riset selanjutnya:

1. Prinsip keadilan berpengaruh terhadap stakeholders perseroan terbatas.

2. Prinsip transparansi berpengaruh terhadap stakeholders perseroan terbatas. 


\section{Saran}

Berdasarkan kesimpulan di atas, maka saran pada artikel ini adalah bahwa masih banyak faktor lain yang mempengaruhi stakeholders perseroan terbatas selain dari prinsip keadilan dan prinsip transparansi pada semua tipe dan level perseroan terbatas. Oleh karena itu masih di perlukan kajian yang lebih lanjut untuk mencari faktor-faktor lain apa saja yang dapat memepengaruhi stakeholders perseroan terbatas selain yang varibel yang di teliti pada arikel ini. Faktor lain tersebut seperti prinsip tanggung jawab dan prinsip akuntabilitas.

\section{DAFTAR PUSTAKA:}

Achmad, A. (2012). Persepsi stakeholders atas penerapan good corporate governance (GCG) pada PT PINDAD (Persero) Bandung. Program Studi Akuntansi Fakultas Ekonomi Universitas Widyatama.

Aprilliani, Dian. (2015). Penerapan prinsip keadilan dalam good corporate governance terhadap pemenuhan hak-hak pemegang saham minoritas. Jurnal Ilmu Hukum Legal Opinion, 3(1).

Erlina, E. (2017). PRINSIP GOOD CORPORATE GOVERNANCE PADA PERSEROAN TERBATAS. Jurisprudentie: Jurusan Ilmu Hukum Fakultas Syariah Dan Hukum, 4(1), 26. https://doi.org/10.24252/jurisprudentie.v4i1.3662

Hartanto, J. A., \& Sulaksono. (2019). Applications of good corporate governance relating to shareholders, commissioners, and directors of limited liability companies in Indonesia. Problems and Perspectives in Management, 17(3), 410-420. https://doi.org/10.21511/ppm.17(3).2019.33

Hirman, Purwanti Y., \& Nugroho S. S.. (2017). Hukum perseroan terbatas. Solo, Indonesia: Pustaka Iltizam.

Lany, A. (2015). Kepastian dan perlindungan hukum dalam pendirian perseroan terbatas melalui sistem administrasi badan hukum menurut undang-undang nomor 40 tahun 2007 tentang perseroan terbatas. PADJADJARAN Jurnal Ilmu Hukum (Journal of Law), 2(2), 291-312. https://doi.org/10.22304/pjih.v2n2.a5

Marthin, M., Salinding, M. B., \& Akim, I. (2018). IMPLEMENTASI PRINSIP CORPORATE SOCIAL RESPONSIBILITY (CSR) BERDASARKAN UNDANGUNDANG NOMOR 40 TAHUN 2007 TENTANG PERSEROAN TERBATAS.

Journal of Private and Commercial Law, 1(1), 111-132. https://doi.org/10.15294/jpcl.v1i1.12358

Oliver, G. (2016). Prinsip dan penerapan transparansi dalam laporan tahunan perseroan terbatas menurut undang-undang no. 40 tahun 2007. Jurnal Lex et Societatis, 4(2), 7178.

PERLINDUNGAN HUKUM TERHADAP PEMEGANG SAHAM MINORITAS PADA PERSEROAN TERBATAS TERBUKA BERDASARKAN PRINSIP FAIRNESS GOOD CORPORATE GOVERNANCE. (2019). TRANSPARENCY, 1(1). 